\title{
IMPROVING PUBLIC AWARENESS OF EARTHQUAKE-RESISTANT HOUSE USING FACTOR ANALYSIS
}

\author{
Agus Dwi Hariyanto ${ }^{1,2 *}$, Sugeng Triyadi ${ }^{3}$, Andry Widyowijatnoko ${ }^{3}$, \\ ${ }^{1}$ Doctoral Program of Architecture; School of Architecture, Planning, and Policy Development, \\ Institut Teknologi Bandung, Jl. Ganesha 10 Bandung, INDONESIA \\ ${ }^{2}$ Department of Architecture, Petra Christian University, Jl. Siwalankerto 121-131, Surabaya, INDOESIA \\ ${ }^{3}$ Building Technology Research Group; School of Architecture, Planning, and Policy Development, \\ Institut Teknologi Bandung, Jl. Ganesha 10 Bandung, INDONESIA \\ *Corresponding author; Email: adwi@petra.ac.id; adwihariyanto73@gmail.com
}

\begin{abstract}
Public awareness of earthquake-resistant houses can increase the region's resilience to earthquake disasters. This study aims to conduct a comparison of two different groups of people on their opinion of earthquake-resistant housing variables and actions to increase the quality of their house. For supporting public awareness of earthquake-resistant houses, the purpose also determines the latent variables of earthquake-resistant houses and actions from the public for improving the quality of the residential building. This quantitative research begins by collecting the earthquake-resistant house attributes through journal reviews. This study used a closed-ended questionnaire to collect data on public experiences of earthquake disasters. For data analysis, it used correlation analysis to determine the level of relationship between two variables and utilizes factor analysis to reduce the variable to a small number of factors. The two groups that have different experiences of earthquakes tend to have similar opinions about the characteristics of earthquake-resistant houses and the actions for improving the quality of residential buildings. The five factors of the earthquake-resistant housing are safe structural construction, fixed architectural elements, open accessibility, lightweight-ductile material, and simple floor plan. Then the three factors represent the actions for improving residential quality, namely, to improve material and structure, build an earthquake-resistant house, and make accessibility easy and safe.
\end{abstract}

Keywords: Public awareness; experience of earthquake; education level; earthquake-resistant houses; factor analysis.

\section{INTRODUCTION}

The physical environment, social, and economic conditions of the community affect vulnerability to disasters (Singh, Eghdami \& Singh, 2014). Besides the decline in the physical environment, social and economic environmental conditions can reduce the ability of people to deal with natural disasters (BNPB, 2014). But on the contrary, improving the quality of the physical environment, social and economic capacity, reduce vulnerability to natural disasters. Increased social capacity, such as community awareness of disaster risk individually or collectively, reduce vulnerability to disasters significantly (IFRC \& FCS, 2011). According to Kung \& Chen (2012), people who have experience with natural disasters have more awareness in doing to reduce disaster risks, when compared to those who have never experienced them. A person's experience with earthquakes can be a trigger to increase their knowledge of the earthquake's disaster around their neighborhood (Damayanti \& Sagala, 2013).

A residential house is a domestic scale building to fulfill the security of its inhabitants, both to climate conditions and the effects of natural disasters such as earthquakes. The initial step in raising public awareness independently in the context of earthquake disaster is to know and understand the attributes or characteristics of the earthquake-resistant house. Structural and non-structural factors influence the resilience of houses against earthquakes (Hariyanto et al., 2016). Structural factors consist of variables, including responsive structures, appropriate materials, simple forms, and stable soil conditions (Kusumastuti et al., 2008; Harmankaya \& Soyluk, 2012). Nonstructural factors are undamaged architectural elements during an earthquake, the ease of occupants saving themselves (Mora et al., 2015) and the proper implementation of construction (Arya et al., 2014). The variables of the two factors then develop into nineteen attributes that characterize earthquake-resistant houses. There are 10 variables in the structural category, namely stable structure, firm structure, ductile structure, lightweight material, ductile material, quality material, simple symmetry floor plan, regular floor plan, solid soil, stable soil (Kusumastuti et al., 2008; Harmankaya \& Soyluk, 2012; Ozmen \& Unay, 2007). There are 9 variables in the nonstructural category, namely accessible openings, fixed molding, fixed wall ornament, fixed ceiling ornament, 
simple spatial layout, alternative exit-door, a chance for self-save, constructions as planned, and construction as per requirements (Mora et al., 2015; Arya et al., 2014). This large number of variables makes it difficult for the public to remember and understand them. According to Vicente, Ferreira, Maio, Koch (2014), simple and easy to understand communication is an effective way to increase public awareness. For that, we need an effort to reduce the number of attributes. For this reason, this research intends to find the primary factor of earthquake-resistant houses. The find of this main factor supports the public in understanding earthquake-resistant houses variables so that it has a positive impact on public awareness of earthquake-resistant houses.

Building construction without involving experts has an impact on houses that are vulnerable to earthquakes (Damayanti \& Sagala, 2013). For that to improve the quality of residential building for seismic resilience, building owners must involve professionals or building experts when building an earthquakeresistant house. Some experts say that building owners may improve building structures (Damayanti \& Sagala, 2013), reduce ornaments, walls, ceilings, and roofing materials (Mora et al., 2015) when renovating their building. They also state in terms of building form; it is safer a regular or symmetry floor plan than an irregular floor plan (Harmankaya \& Soyluk, 2012). A simple floor plan can improve accessibility, especially if there are some exit doors. Residents can easily save themselves when an earthquake strike. In general, the design and construction have to meet the building requirements (Arya et al., 2014) for ensuring building resilience of seismic. Building design and construction as per requirements are also part of the disaster mitigation efforts to reduce seismic vulnerability. The last effort for personal and family safety is moving to a location or area that is not prone to earthquakes due to unstable soil conditions or located in areas that have a seismic vulnerability (Ozmen \& Unay, 2007). So, for improving the quality of their houses to be earthquake resistant, residential building owners must conduct 11 actions. The structural category included to improve the structure, roof material, wall material, ceiling material, simplify floor plan, and reduce ornaments. The non-structural category included to add exit doors, involve building experts, and move building location. The planning and construction category included actions to build according on requirements and build earthquakeresistant houses. This large number of variables makes it difficult for the public to remember and understand them. For this reason, this study intends to find priority actions to support the public in improving the quality of their houses so that it has a positive impact on public awareness of earthquakeresistant houses.

This study aims to conduct a comparison of public opinion on earthquake-resistant housing variables and actions to increase the quality of the house from two different groups. The two groups are those who have and have never experienced an earthquake. In addition to supporting efforts to increase public awareness of earthquake-resistant houses variables, this study also aims to determine the main factors of earthquake-resistant houses and priority actions from the public for improving the quality of their residential building.

\section{RESEARCH METHODS}

This quantitative research begins by collecting secondary data and primary data. Secondary data were obtained through a journal review to find out the results of research on earthquake-resistant house attributes and actions for improving the residential building quality for seismic resilience. The 19 attributes of earthquake-resistant house were retrieved, namely "stable structure", "firm structure", "ductile structure", "lightweight material", "ductile material", "quality material", "simple symmetry floor plan", "regular floor plan", "solid soil", "stable soil", "accessible openings", "fixed molding", "fixed wall ornament", "fixed ceiling ornament", "simple spatial layout", "alternative exit-door", "a chance for self-save", "constructions as planned", and "construction as per requirements". The 11 actions for improving the residential building quality for seismic resilience were retrieved, namely "improve the structure", "improve roof material", "improve wall material", "improve ceiling material", "simplify floor plan", "reduce ornaments", "add exit doors", "involve building experts", "move location", "build according on requirements", and "build earthquake-resistant house".

The objects in this study are earthquake-resistant houses, public opinion of their attributes, and actions for improving residential building for seismic resilience. The opinions were from the two groups which have or have never experienced an earthquake. Thus, we also investigated the community's experience of the earthquake disaster, whether it affected their assessment of earthquake-resistant housing variables and actions for improving the houses or not. We use secondary data about these attributes and actions to create a closed-ended questionnaire. We collect primary data by distributing questionnaires online to the public community. 
For collecting primary data, we asked respondents to answer online closed-ended questionnaires to collect data on their house and experiences of earthquake disasters. In the section about respondents' opinions on earthquake-resistant house attributes and actions for improving residential building, respondents respond with a Likert scale (1 to 5). The choice of number 1 represents the opinion disagree, number 2 slightly disagree, number 3 is neutral, number 4 slightly agree, and number 5 shows the respondent agrees with the statement in the questionnaire. Table 1 shows the sample questions about respondent actions to improve the house quality based on his/her experience and knowledge about the earthquake. Table 2 shows the sample questions about the respondent's perception of earthquake-resistant houses. Respondents agree more with the statement when he/she choose a higher number. The use of Likert scale is appropriate because we can use this scale to assess the attitudes, opinions, and perceptions of a person or group about an event or social phenomenon (Riduwan \& Sunarto, 2010; Croasmun \& Ostrom, 2011). Data collection runs from November $3^{\text {rd }}, 2016$ to December $31^{\text {st }}, 2016$. We have a total number of respondents, 150 people from various cities in 20 provinces in Indonesia. The number of respondents was $87(58 \%)$ men and women $63(48 \%)$.

For data analysis, this study uses distribution analysis, contingency table analysis, correlation analysis, factor analysis, and multivariate analysis. Distribution analysis (Neuman, 2014) to determine the percentage of respondents' education, public opinions on earthquake-resistant house attributes, and public opinions on actions for improving their residential building. The contingency table analysis approach can summarize the frequencies of observations in each variable category (Kateri, 2014). So, this study uses it to summarize the frequency of education level of respondents and building experts involved in building houses, as well as the level of education with experience of earthquakes. According to Riduwan \& Sunarto (2010), researchers can use correlation analysis to determine the level of relationship between two variables. For this reason, we use correlation analysis to find out the relationship between respondents who have and who have never experienced an earthquake. The analysis is to reveal whether there are opinion differences between the two groups of respondents. After that, to reduce the variable to a small number of factors, this study utilizes factor analysis, namely principal component analysis (PCA). With this analysis, we can summarize the pattern of correlations between variables to get factors that are independent of one another (Jolliffe, 2002; Abdi \& Williams, 2010). To complete the nalysis factor, we used the value of Cronbach's Alpha reliability items, the mean, and standard deviations. Researchers can use multivariate analysis to obtain

Table 1. Sample Questions about Respondent Actions to Improve the House Quality Based on Experience and Knowledge about the Earthquake based on Likert Scale

\begin{tabular}{lccccc}
\hline Questions & Disagree & $\begin{array}{c}\text { Slightly } \\
\text { disagree }\end{array}$ & Neutral & $\begin{array}{c}\text { Slightly } \\
\text { agree }\end{array}$ & Agree \\
\hline Improve building structure & 1 & 2 & 3 & 4 & 5 \\
Simplify floor plan & 1 & 2 & 3 & 4 & 5 \\
Involve building experts & 1 & 2 & 3 & 4 & 5 \\
\hline
\end{tabular}

Table 2. Sample Questions about Respondents' Perception of Earthquake-Resistant Houses based on Likert Scale

\begin{tabular}{lccccc}
\hline Questions & Disagree & $\begin{array}{c}\text { Slightly } \\
\text { disagree }\end{array}$ & Neutral & $\begin{array}{c}\text { Slightly } \\
\text { agree }\end{array}$ & Agree \\
\hline $\begin{array}{l}\text { Firm building structures } \\
\text { support the resilience of } \\
\text { houses against earthquakes. }\end{array}$ & 1 & 2 & 3 & 4 & 5 \\
$\begin{array}{l}\text { Lightweight building } \\
\text { materials support the house's } \\
\text { resistance to earthquakes. }\end{array}$ & 1 & 2 & 3 & 4 & 5 \\
$\begin{array}{l}\text { Symmetrical and simple } \\
\text { floor plans are safe against } \\
\text { earthquakes }\end{array}$ & 1 & 2 & 3 & 4 & 5 \\
\hline
\end{tabular}


the value of Cronbach's alpha reliability items (Cronbach, 1951; Croasmun \& Ostrom, 2011). The value of the reliability item, which is close to 1.00 , indicates that the reliability is high. In general, if the item value $\geq 0,700$ is considered good enough. For this reason, this study uses multivariate analysis to test the reliability of respondents' opinions on 19 variables of earthquake-resistant houses dan opinions on 11 actions for improving their residential building quality for seismic resilience. We conducted a multivariate correlation analysis to determine the relationship between the opinions of the two groups of respondents. The extrapolation was using the average value of each question by each group of respondents. Then we use the scatterplot matrix to show the results.

\section{RESULTS AND DISCUSSION}

From the Contingency Table 3, the education level of respondents who have a bachelor's degree dominates almost half of the total respondents (48\%), followed by master's degree (34\%), high school
(11\%), and the lowest percentage is a doctoral degree $(7 \%)$. The level of education indicates that most respondents are highly educated people so that they might have well informed about earthquake-resistant houses. But in table 3 shows an exciting finding, namely the frequency of respondents who chose to build houses without involving experts. Their frequency has more percentage $(51.33 \%)$ than those involving experts $(48.67 \%)$. Respondents that prefer to build without involving experts than involving experts are those who have high school education (82.35\% compared to $17.65 \%$ ), as well as those who have a master's degree $(58.82 \%$ compared to $41.18 \%$ ). Meanwhile, those who have a bachelor's degree prefer to involve building experts $(54.17 \%)$, as well as those who have a doctoral degree $(100 \%)$ in building their residential building. So, the fact in this study is the higher the level of education, the higher the frequency in involving experts to build houses. Different result only appears in the group of master's degrees who have less frequency in involving experts than those who have a bachelor's degree. Damayanti

Table 3. Education Level of Respondents and How to Build Houses

\begin{tabular}{|c|c|c|c|c|c|c|c|}
\hline & & & \multicolumn{4}{|c|}{ Education Level of Respondents } & \multirow[b]{2}{*}{ Total } \\
\hline & & & $\begin{array}{c}\text { High } \\
\text { school } \\
\text { (SMA) }\end{array}$ & $\begin{array}{c}\text { Bachelor's } \\
\text { degree (S1) }\end{array}$ & $\begin{array}{c}\text { Master's } \\
\text { degree } \\
(\mathrm{S} 2)\end{array}$ & $\begin{array}{c}\text { Doctoral } \\
\text { degree } \\
(\mathrm{S} 3) \\
\end{array}$ & \\
\hline \multirow{10}{*}{ 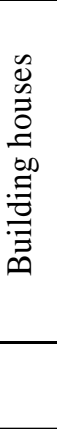 } & Building houses & Count & 14 & 33 & 30 & 0 & 77 \\
\hline & without experts & Total \% & 9.33 & 22.00 & 20.00 & 0 & 51.33 \\
\hline & (architects and or & Col \% & 82.35 & 45.83 & 58.82 & 0 & \\
\hline & contractors) & Row \% & 18.18 & 42.86 & 38.96 & 0 & \\
\hline & Building houses by & Count & 3 & 39 & 21 & 10 & 73 \\
\hline & involving experts & Total \% & 2.00 & 26.00 & 14.00 & 6.67 & 48.67 \\
\hline & (architects and or & Col \% & 17.65 & 54.17 & 41.18 & 100.00 & \\
\hline & contractors) & Row $\%$ & 4.11 & 53.42 & 28.77 & 13.70 & \\
\hline & Total (count) & & 17 & 72 & 51 & 10 & 150 \\
\hline & Total $(\%)$ & & 11.33 & 48.00 & 34.00 & 6.67 & 100.00 \\
\hline
\end{tabular}

Table 4. Education Level of Respondents and Their Experience of an Earthquake

\begin{tabular}{|c|c|c|c|c|c|c|c|}
\hline & & & \multicolumn{4}{|c|}{ Education Level of Respondents } & \multirow[b]{2}{*}{ Total } \\
\hline & & & $\begin{array}{c}\text { High } \\
\text { school } \\
\text { (SMA) }\end{array}$ & $\begin{array}{c}\text { Bachelor's } \\
\text { degree (S1) }\end{array}$ & $\begin{array}{l}\text { Master's } \\
\text { degree } \\
\text { (S2) }\end{array}$ & $\begin{array}{l}\text { Doctoral } \\
\text { degree } \\
\text { (S3) }\end{array}$ & \\
\hline \multirow{10}{*}{ 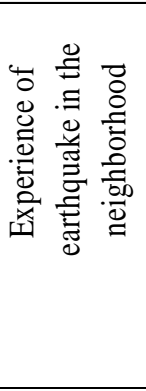 } & \multirow{4}{*}{ Have no experience } & Count & 4 & 29 & 15 & 5 & 53 \\
\hline & & Total $\%$ & 2.67 & 19.33 & 10.00 & 3.33 & 35.33 \\
\hline & & $\mathrm{Col} \%$ & 23.53 & 40.28 & 29.41 & 50.00 & \\
\hline & & Row \% & 7.55 & 54.72 & 28.30 & 9.43 & \\
\hline & \multirow{4}{*}{ Have experience } & Count & 13 & 43 & 36 & 5 & 97 \\
\hline & & Total \% & 8.67 & 28.67 & 24.00 & 3.33 & 64.67 \\
\hline & & $\mathrm{Col} \%$ & 76.47 & 59.72 & 70.59 & 50.00 & \\
\hline & & Row \% & 13.40 & 44.33 & 37.11 & 5.15 & \\
\hline & Total (count) & & 17 & 72 & 51 & 10 & 150 \\
\hline & Total $(\%)$ & & 11.33 & 48.00 & 34.00 & 6.67 & 100.00 \\
\hline
\end{tabular}


\& Sagala (2013) found a relationship between the low level of knowledge of the population and the resilience of the house to the earthquake and the low level of involvement of experts in building residential houses in the Lembang fault area. So, there is a positive relationship between the level of education and the involvement of building experts in housing construction.

From Contingency Table 4, respondents who have experienced an earthquake in the neighborhood are more than those who have never experienced it (64.67\% compared to $35.33 \%$ ). In the three respondent groups, those who have experienced earthquakes have more frequencies than those who have never experienced it. They have frequency $76.47 \%$ compared to $23.53 \%$ for the high school respondent's group, $59.72 \%$ compared to $40.28 \%$ for the bachelor's degree group, and $70.59 \%$ compared to $29.41 \%$ for the master's degree group. In the group with a doctoral degree, each has the same frequency of $50 \%$. The experience of earthquakes with education levels do not correlate. But both can influence the respondent's opinion on the attributes of earthquake-resistant houses and the actions that need to improve the quality of their residential building to have seismic resilience. According to Kung \& Chen (2012), people who have experience with natural disasters have more awareness in doing to reduce disaster risks, when compared to those who have never experienced them. Next, the discussion is about a comparison of the opinions and actions of two groups. They have experienced and have never experienced earthquakes in their neighborhood.

\section{Public Opinion on Earthquake-Resistant House Variables and Actions for Improving Residential Building Quality}

Figure 1 shows the results of a questionnaire with a Likert scale about respondents' opinions on earthquake-resistant attributes or variables. The figure shows the frequency distribution of the respondents' opinions. The "construction as per requirements" variable gets the highest percentage of approval from respondents $(65.3 \%)$. The feature that gets the highest percentage proves that the public perceives the implementation of the construction as per the requirements as the variable that most influences the quality of residential buildings for earthquake resistance compared to 18 other features. This finding is in line with Arya, et al. (2014) that said for new construction, meeting building regulations and their implementation is an essential safeguard against seismic vulnerability. The "chance for self-save" variable becomes the second one chosen by most respondents (64\%). So, the selection of the variable "chance for self-save" proves that self-safety is a critical and public concern. This finding is in line with Mora, et al. (2015). They found that the public perception of the essential feature of safe building on seismic resilience was the provision of safe exits from building rather than building materials.

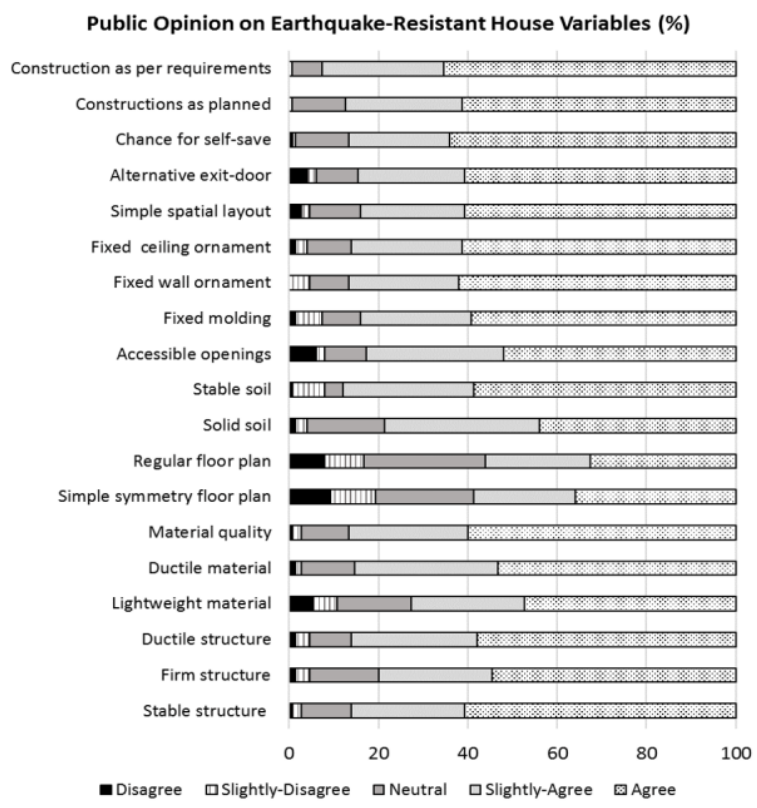

Figure 1. Public Opinion on Earthquake-Resistant House Variables

Figure 2 shows the results of distribution analysis about respondents' opinions on actions to improve the quality of residential building on seismic resilience. The two highest respondent's approval goes for actions of "build according on requirements" and "build an earthquake-resistant house." The actions of "build according on requirements" get the highest approval, $61 \%$ of respondents agree with it. Public perception of the 'build according on requirements' action when planning, building, or renovating houses is an action that is in line with the 'construction as per requirements' variable. This variable gets the highest approval level of respondents for seismic resilience home building features. This finding is interesting because there is a consistency between opinions on earthquake-resistant house characteristics and actions to improve the quality of the house so that it has seismic resilience. The consistency of these two things is also in line with the statement of Arya, et al. (2014) that meeting building regulations for building design and construction are a critical safeguard against seismic vulnerability. The actions of "build an earthquake-resistant house" gets the second-highest 
approval, $47 \%$ of respondent agreement. The action of building a seismic resilience house is a comprehensive action that covers all stages of planning and building construction in seismic prone areas. For this reason, the public perception of this action is very positive and supportive. Then, the next actions to improve the quality of residential buildings are to "improve building structure," "involve building experts," and "reduce ornaments" in the interior of the house. These three actions get the respondents' approval of an average of $42 \%$.

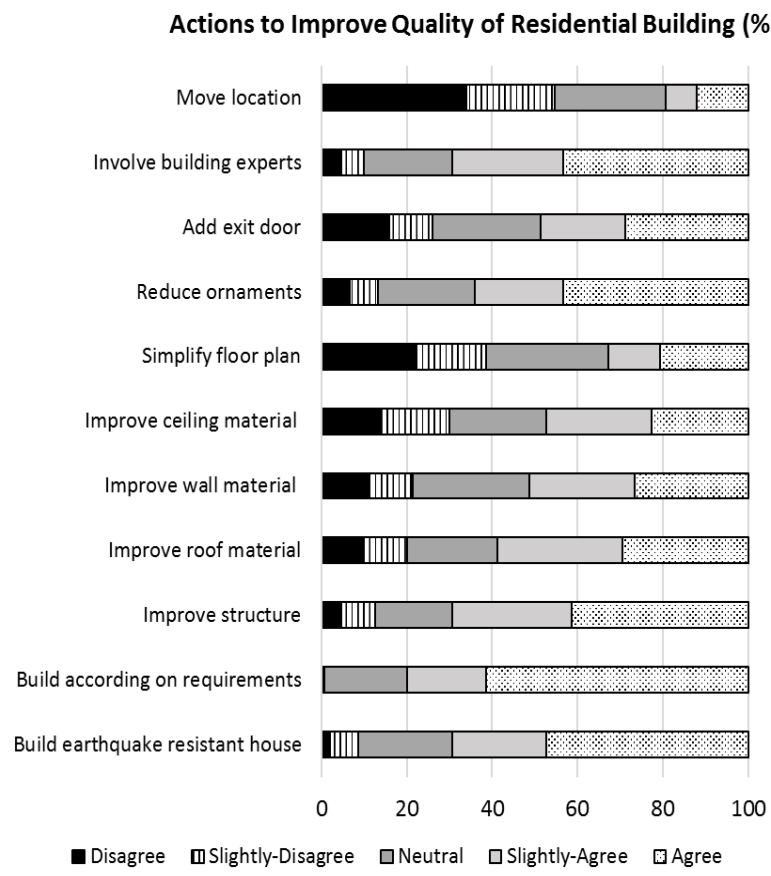

Figure 2. Public Action to Improve Quality of Residential Building

Figure 2 shows "move location" and "simplify floor plan" are two actions that are difficult for respondents to perceive. The first action is "move location," 34\% of respondents are disagree with it. In general, people have an attachment to the place of residence where they live, have a family, work, children go to school, so they do not agree for moving even though the location has a seismic vulnerability. Ozmen \& Unay (2007) stated that moving to a location or area that is not prone to an earthquake is the last effort for personal and family safety. The second most unapproved action was the "simplify floor plan," $22 \%$ of respondents disagree with it. People are reluctant to simplify their house plans because they think this is not a problem, even though a simple floor plan can improve accessibility and symmetry of a floor plan can reduce torsion in buildings during an earthquake (Harmankaya \& Soyluk, 2012).

\section{Comparison of Two Groups of Respondents}

Figures 3 and 4 show an interesting phenomenon about two groups that have different experiences but tend to have almost similar opinions about the characteristics of earthquake-resistant houses and actions for improving the quality of their residential buildings. They give opinions on a Likert Scale: values 1 (disagree), 2 (slightly-disagree), 3 (neutral), 4 (slightly-agree), and 5 (agree). The first is a group that has experienced an earthquake in their neighborhood. The second is a group that has never experienced it. The average value of respondents' opinions on the features of the earthquake-resistant houses can be seen in the line chart in figure 3 . It shows that the variables "simple symmetry floor plan" and "regular floor plan" are the two attributes that are on the rating scale 3 (neutral) to 4 (slightly agree), while seventeen other variables are on the rating scale 4 (slightly agree) to 5 (agree). The results show that both groups positively assessed the 19 variables as characteristics of earthquake-resistant houses. In the last two attributes, "construction as planned" and "construction as per requirements," the lines chart overlap.

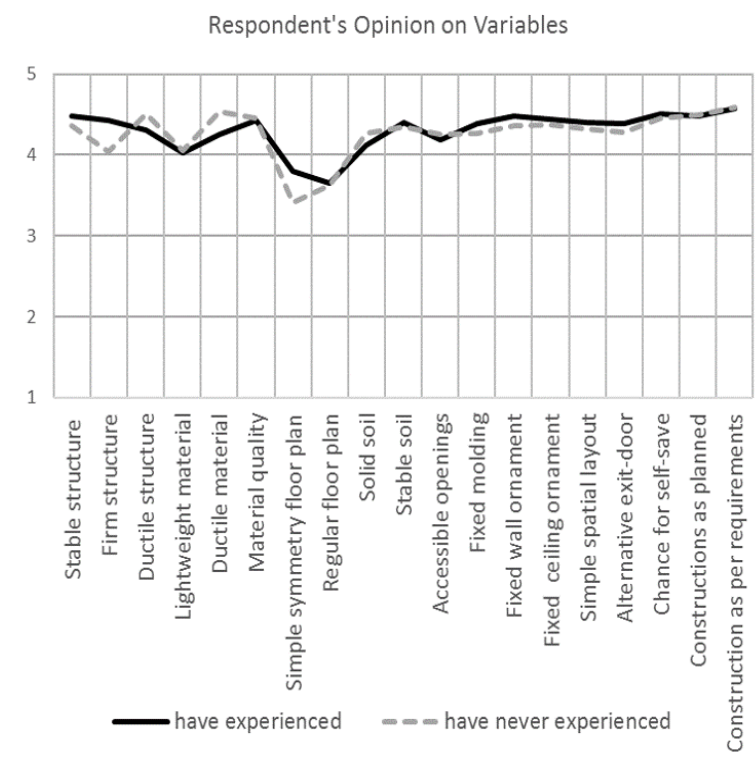

Figure 3. The Average Value of Respondents' Opinions on Earthquake Resistant Houses Attributes. Opinions on a Likert Scale: values 1 (Disagree), 2 (Slightly-Disagree), 3 (Neutral), 4 (Slightly-Agree), and 5 (Agree).

The facts prove that the two community groups equally consider that the aspect of construction implementation is very influential on the quality of earthquake-resistant houses. In the opinion of improving the quality of their residential building, the average of the two groups' opinions even has almost a similar trend, as seen in figure 4 . The results show that 
both groups positively assessed the 11 actions for improving residential building on seismic resilience. The line chart shows that the actions of "move location" has the lowest average that is on the rating scale 2 (slightly-disagree) - 3 (neutral). The secondlowest average is "simplify the floor plan," which has a rating near to 3 (neutral). The action of "build according on requirements" has the highest average on the rating 4 (slightly-agree) to 5 (agree). The facts of lines chart overlap in some points prove that the two groups have equally perceptions about these actions.

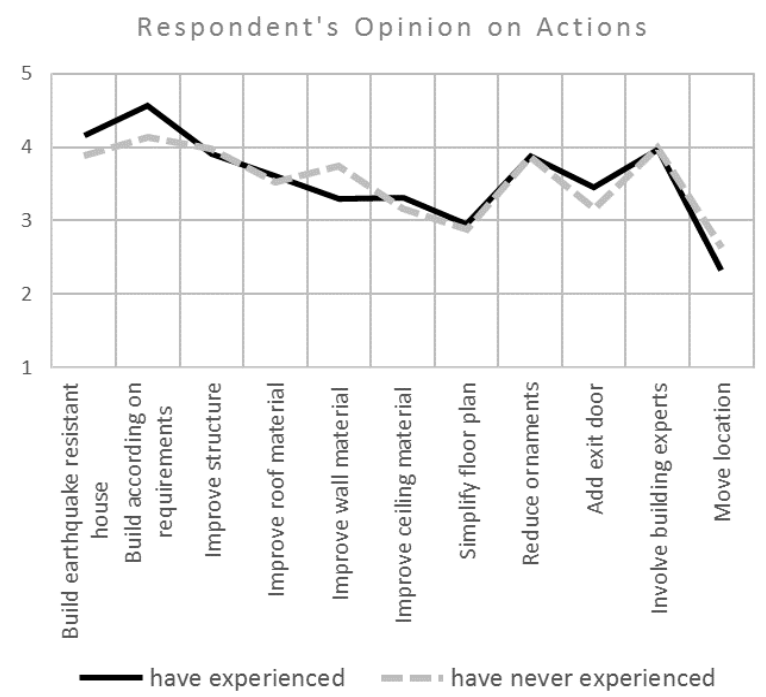

Figure 4. The Average Value of Respondents' Opinions on Actions to Improve the Quality of Residential Building. Opinions on a Likert Scale: values 1 (Disagree), 2 (SlightlyDisagree), 3 (Neutral), 4 (Slightly-Agree), and 5 (Agree).

Next, we performed a multivariate correlation analysis to find out the level of relationship between the opinions of the two groups of respondents. In figure 5 and 6 , shows the relationship between them on the opinions of earthquake-resistant house attributes and the opinions of actions for improving the quality of the residential building. They show a correlation between the two groups with a coefficient value of $r=0.84$ and $r=0.92$, respectively. Sugiyono (2017) said that the correlation coefficient in the range of 0.80 - 1 has a great relationship. So, the relationship is a strong correlation, and in the same direction because the results are positive. This result shows that there is no significant difference in opinions between the two groups of respondents. The facts are interesting because different experiences do not affect people's understanding and perception of earthquakeresistant house characteristics and actions for improving their residential building. Both groups of people have the same opinion about the variables and actions. The finding differs from the opinions of Kung \& Chen (2012) states that people who have experience with natural disasters have more awareness in doing to reduce disaster risks when compared to those who have never experienced them. The level of education and adequate knowledge about earthquakeresistant houses might influence the respondents' perception. So, the factor of education level is more influential than the experience in this discussion.

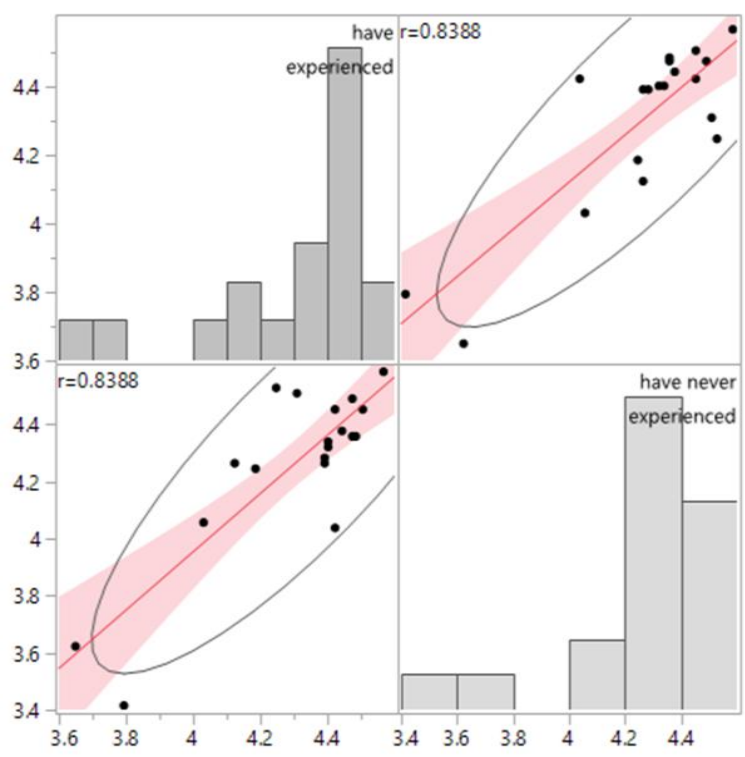

Figure 5. Multivariate Correlation Analysis Result of Two Respondent Groups' Opinion on Earthquake Resistant House Variables

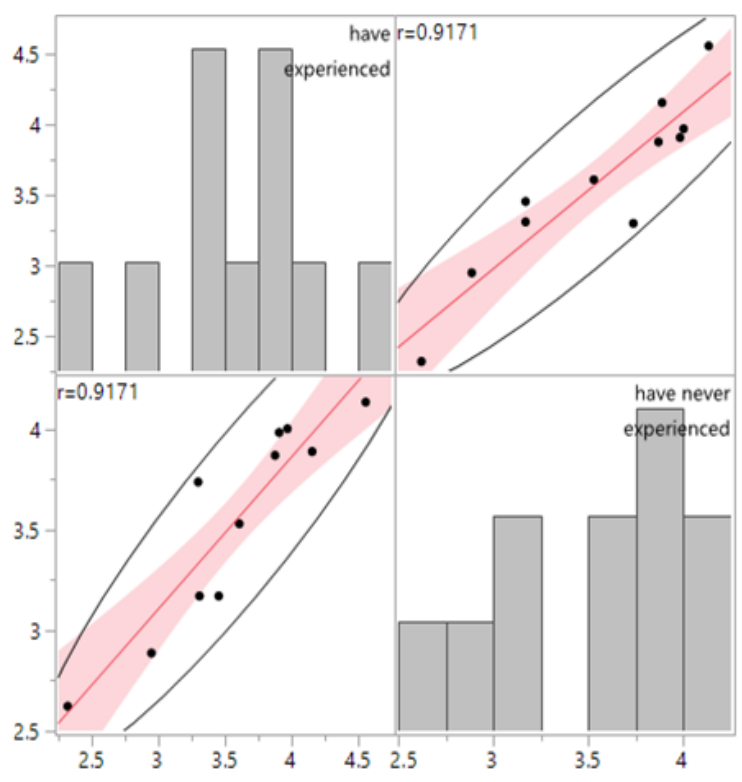

Figure 6. Multivariate Correlation Analysis Result of Two Respondent Groups' Opinion on Action to Improve the Quality of Residential Building 


\section{Variable Reduction and Naming Factors}

For public observation, there are 19 variables for earthquake-resistant house and 11 actions to improve the quality of residential building on seismic resilience. The many variables and actions make it difficult for people to remember and understand one by one. For this reason, we do principal component analysis (PCA) to find the principal components that have an eigenvalue greater than 1 . Their values exceed the variability of the measured variables, so they can represent the variables (Kaiser, 1960). The PCA results for earthquake-resistant housing variables, there were five principal components that have an eigenvalue greater than 1 . The cumulative percentage is $68.01 \%$. This percentage is enough to describe and represent the phenomenon of the 19 variables measured. In the variable distribution rotation stage, this process produces 5 matrix component rotations. The amount is following the number of factors resulting from the variable distribution due to the rotation process. So, there are 5 groups of variables. Table 5 shows the results of the rotation distribution of earthquake-resistant housing variables. The five latent variables (factor 1 to 5), represent the 19 earthquake-resistant housing variables, namely "safe structural construction", "fixed architectural elements", "open accessibility", "lightweight-ductile material ", and "simple floor plan" respectively.
In table 5, the first group (Factor 1), high correlated variables are construction as planned, construction as per requirements, stable structure, material as per requirements, chance for self-save, and firm structure. In the second group (Factor 2), the highly correlated variables were fixed ceiling ornament, fixed wall ornament, and fixed molding. The third group (Factor 3 ), high correlated variables are alternative exit-door, simple spatial layout, and accessible openings. In the fourth group (Factor 4), high correlated variables are ductile material, ductile structure, and lightweight materials. In the last group (Factor 5), the variables that are highly correlated are the regular floor plan, simple symmetry floor plan, solid soil, and stable soil. Therefore, from observing 19 variables, it can produce 5 main factors. The five factors of earthquakeresistant houses are simpler and easier to understand. Vicente et al. (2014) state that simple and easy to understand communication is an effective way to increase public awareness. So, the finding of the five factors can support for increasing public awareness of the earthquake resistant house.

Next, the PCA results for actions to improve residential building quality, three principal components have an eigenvalue greater than 1 , with a cumulative percentage of $59.5 \%$. This percentage is considered enough to describe and represent the phenomenon of 11 measured variables. In the variable

Table 5. Factor Analysis Results with Varimax Rotation of Five Principal Components

\begin{tabular}{|c|c|c|c|c|c|}
\hline & Factor 1 & Factor 2 & Factor 3 & Factor 4 & Factor 5 \\
\hline Variable & $\begin{array}{l}\text { Safe structural } \\
\text { construction }\end{array}$ & $\begin{array}{c}\text { Fixed } \\
\text { Architectural } \\
\text { elements }\end{array}$ & $\begin{array}{c}\text { Open } \\
\text { Accessibility }\end{array}$ & $\begin{array}{l}\text { Lightweight } \\
\text { ductile } \\
\text { material }\end{array}$ & $\begin{array}{c}\text { Simple floor } \\
\text { plan }\end{array}$ \\
\hline Constructions as planned & 0.79 & 0.21 & 0.24 & 0.14 & -0.02 \\
\hline Construction as per requirements & 0.76 & 0.18 & 0.21 & 0.22 & -0.01 \\
\hline Stable structure & 0.65 & 0.12 & 0.01 & 0.12 & 0.19 \\
\hline Material as per requirements & 0.62 & 0.19 & 0.00 & 0.28 & 0.08 \\
\hline Chance for self-save & 0.58 & 0.08 & 0.16 & 0.13 & 0.19 \\
\hline Firm structure & 0.49 & 0.11 & -0.10 & -0.02 & 0.39 \\
\hline Fixed ceiling ornament & 0.15 & 0.77 & 0.35 & 0.10 & 0.22 \\
\hline Fixed wall ornament & 0.34 & 0.75 & 0.12 & 0.19 & -0.01 \\
\hline Fixed molding & 0.19 & 0.73 & 0.12 & 0.14 & 0.13 \\
\hline Alternative exit-door & 0.14 & 0.12 & 0.91 & 0.01 & 0.11 \\
\hline Simple spatial layout & 0.17 & 0.21 & 0.71 & 0.25 & 0.25 \\
\hline Accessible openings & 0.05 & 0.25 & 0.52 & 0.09 & 0.26 \\
\hline Ductile material & 0.34 & 0.13 & 0.13 & 0.74 & 0.03 \\
\hline Ductile structure & 0.10 & 0.02 & 0.05 & 0.61 & 0.12 \\
\hline Lightweight material & 0.13 & 0.28 & 0.09 & 0.51 & 0.11 \\
\hline Regular floor plan & 0.13 & 0.10 & 0.32 & 0.10 & 0.57 \\
\hline Simple symmetry floor plan & 0.09 & 0.04 & 0.30 & 0.15 & 0.49 \\
\hline Solid soil & 0.16 & 0.21 & 0.12 & 0.39 & 0.39 \\
\hline Stable soil & 0.20 & 0.31 & 0.11 & 0.28 & 0.33 \\
\hline
\end{tabular}


Table 6. Factor Analysis Results with Varimax Rotation of Three Principal Components

\begin{tabular}{lrrr}
\hline & Factor 1 & Factor 2 & Factor 3 \\
\cline { 2 - 4 } \multicolumn{1}{c}{ Public Action } & $\begin{array}{c}\text { Improve } \\
\text { material and } \\
\text { structure }\end{array}$ & $\begin{array}{c}\text { Build } \\
\text { earthquake } \\
\text { resistant house }\end{array}$ & $\begin{array}{c}\text { Make } \\
\text { accessibility } \\
\text { easy and safe }\end{array}$ \\
\hline Improve ceiling material & $\mathbf{0 . 8 0}$ & -0.01 & 0.26 \\
Improve roof material & $\mathbf{0 . 7 0}$ & 0.01 & 0.30 \\
Improve wall material & $\mathbf{0 . 5 2}$ & 0.06 & 0.14 \\
Improve structure & $\mathbf{0 . 4 6}$ & 0.11 & 0.27 \\
Build according on requirements & -0.13 & $\mathbf{0 . 9 2}$ & 0.11 \\
Build earthquake resistant house & 0.20 & $\mathbf{0 . 7 6}$ & 0.01 \\
Add exit door & 0.15 & 0.02 & $\mathbf{0 . 6 2}$ \\
Reduce ornaments & 0.25 & 0.15 & $\mathbf{0 . 5 4}$ \\
Simplify floor plan & 0.46 & 0.03 & $\mathbf{0 . 4 7}$ \\
Move location & 0.19 & -0.02 & $\mathbf{0 . 4 4}$ \\
Involve building experts & 0.30 & 0.27 & $\mathbf{0 . 3 7}$ \\
\hline
\end{tabular}

distribution rotation stage, this process produces 3 matrix component rotations. The amount is following the number of factors resulting from the variable distribution due to the rotation process. So, there are 3 groups of variables. Table 6 shows the results of the rotation distribution of actions to improve the quality of the house. The three latent variables (factor 1 to 3 ) obtained from the factor analysis can be seen in table 6. Three factors represent the 11 actions, namely "improve material and structure", "build an earthquake-resistant house", and "make accessibility easy and safe".

Table 7. The Value of Cronbach's Alpha Reliability Items of Earthquake-Resistant House variables

\begin{tabular}{lc}
\hline \multicolumn{1}{c}{$\begin{array}{c}\text { Earthquake-Resistant House } \\
\text { Variables }\end{array}$} & $\begin{array}{c}\text { Value of Cronbach's } \\
\text { Alpha }(\boldsymbol{\alpha})\end{array}$ \\
\hline Stable structure & 0.877 \\
Firm structure & 0.881 \\
Ductile structure & 0.882 \\
Lightweight material & 0.879 \\
Ductile material & 0.875 \\
Material as per requirements & 0.876 \\
Simple symmetry floor plan & 0.882 \\
Regular floor plan & 0.878 \\
Solid soil & 0.876 \\
Stable soil & 0.876 \\
Accessible openings & 0.878 \\
Fixed molding & 0.875 \\
Fixed wall ornament & 0.874 \\
Fixed ceiling ornament & 0.872 \\
Simple spatial layout & 0.871 \\
Alternative exit-door & 0.877 \\
Chance for self-save & 0.877 \\
Constructions as planned & 0.874 \\
Construction as per requirements & 0.875 \\
\hline Average Value of Cronbach's Alpha $(\alpha)$ & 0.877 \\
Standard deviation & 0.003 \\
\hline
\end{tabular}

In table 6 , the high correlated of action variables for factor 1 are to improve ceiling material, improve roof material, improve wall material, improve structure. In factor 2, the highly correlated action variables are to build according on requirements and build an earthquake-resistant house. In factor 3, the action variables that are highly correlated are to add exit door, reduce ornaments, simplify the floor plan, move location, and involve building experts. Thus, from observing 11 actions, it can produce 3 main factors. The finding of the three factors can support for increasing public awareness of how to improve the residential building quality.

\section{Reliability of Respondents' Opinions}

We tested the reliability of respondents' opinions on 19 earthquake-resistant house variables and 11 actions for improving residential building using the reliability item value analysis of Cronbach's Alpha. The result for the 19 variables, the average value of Cronbach's Alpha reliability items is 0.877 , with a standard deviation of 0.003 (table 7). With an average value of alpha 0.877 , shows the very strength $(>0.8)$ of the reliability of all items and the consistency of respondents' opinions on questions about the 19 variables (Cronbach, 1951; Croasmun \& Ostrom, 2011). Then the result for the 11 actions, the average value of Cronbach's Alpha reliability items, is 0.779, with a standard deviation of 0.013 (table 8). With an average value of alpha 0.779 , shows the strength (>0.7) of the reliability of all items and the consistency of respondents' opinions on questions about the 11 actions (Cronbach, 1951; Croasmun \& Ostrom, 2011). The consistency of these opinions 
might relate to the high cognitive level of the respondents. The educational background of the respondents (89\% highly educated, see Table 3) supports this consistency. Besides, higher education can also erode the influence of the background experience of respondents on disasters. Respondents who have and have never experienced a disaster have the same tendency towards earthquake-resistant house variables.

Table 8. The Value of Cronbach's Alpha Reliability Items of Public Actions for Improving Quality of Residential Building

\begin{tabular}{lc}
\hline $\begin{array}{c}\text { Public Action to Improve Quality of } \\
\text { Residential Building }\end{array}$ & $\begin{array}{c}\text { Value of Cronbach's } \\
\text { Alpha }(\boldsymbol{\alpha})\end{array}$ \\
\hline Build earthquake resistant house & 0.796 \\
Build according on requirements & 0.802 \\
Improve structure & 0.776 \\
Improve roof material & 0.765 \\
Improve wall material & 0.782 \\
Improve ceiling material & 0.762 \\
Simplify floor plan & 0.766 \\
Reduce ornaments & 0.775 \\
Add exit door & 0.784 \\
Involve building experts & 0.777 \\
Move location & 0.789 \\
\hline Average Value of Cronbach's Alpha $(\alpha)$ & 0.779 \\
\hline Standard deviation & 0.013 \\
\hline
\end{tabular}

\section{CONCLUSION}

People's opinions about the characteristics of the earthquake-resistant houses and actions for improving the quality of their house were have analyzed. The opinions were from the two groups which have or have never experienced an earthquake. This research gets results in four findings. The first one was the higher the level of education, the higher the frequency in involving experts to build houses. Different results only appear in the group of master's degrees who have less frequency in involving experts than those who have a bachelor's degree. The second was the two groups that have different experiences of earthquakes tend to have almost similar opinions about the characteristics of earthquake-resistant houses and actions for improving the quality of their residential buildings. The level of education and adequate knowledge about earthquake-resistant houses might influence the respondents' perception. But the person's experience with earthquake disaster might be a trigger to broaden their knowledge of the natural disaster. So, the experience can also be a supportive factor for public awareness. However, in this study, the level of education and adequate knowledge about earthquakeresistant houses was more influential than the people's experience in this case. The next finding was the factors that represent the 19 earthquake-resistant housing variables. They were five latent variables, namely "safe structural construction", "fixed architectural elements", "open accessibility", "lightweight-ductile material", and "simple floor plan". The last finding was three-factors represent the 11 actions for improving the residential building quality. They were three latent variables namely "improve material and structure", "build an earthquake-resistant house", and "make accessibility easy and safe". The five factors and three factors are simpler and easier to understand. However, the community needs to involve experts, mainly from architecture and civil engineering, for planning and implementing earthquake-resistant housing construction to ensure the quality of buildings according to the government's regulation. In the initial findings, awareness to involve experts is related to education level. Therefore, in the future, it is hoped that these findings can support public awareness in each level of education to earthquake-resistant houses because of the higher public consciousness, the better region's resilience to earthquake disasters.

\section{ACKNOWLEDGMENT}

This research was fully funded by the LPDP (Indonesia Endowment Fund for Education). The first author also received support from Petra Christian University (PCU) as the author's home-based institution. We thank LPDP and PCU for the support.

\section{REFERENCES}

Abdi, H., \& Williams, L.J. (2010). Principal Component Analysis. Wiley Interdisciplinary Reviews: Computational Statistics, 2(4), 433-459.

Arya, A.S., Boen, T., \& Ishiyama, Y. (2014). Guidelines for Earthquake Resistant Non-Engineered Construction. United Nations Educational, Scientific and Cultural Organization. France.

BNPB (2014). Indeks risiko bencana Indonesia tahun 2013, Direktorat Pengurangan Risiko Bencana Deputi Bidang Pencegahan dan Kesiapsiagaan.

Croasmun, J.T., \& Ostrom, L. (2011). Using LikertType Scales in the Social Sciences. Journal of Adult Education, (1), 19-22.

Cronbach, L.J. (1951). Coefficient alpha and the internal structure of tests. Psychometrika, 16(3), $297-334$.

Damayanti, P., \& Sagala, S. (2013). Kesiapan Fisik Rumah Masyarakat terhadap Potensi Gempa Bumi di Lembang, Jawa Barat. Working Paper Series Resilience Development Initiative., No. 1, Oktober. 
Geospasial BNPB (2013). Peta Indeks Rawan Bencana Indonesia 2012, http://geospasial.bnpb. go.id/wp-content/uploads/2016/03/2013-0513_ peta_IRBI_2013_rev.jpg. Diunduh tanggal 5 Desember 2016

Hariyanto, A.D., Triyadi, S., \& Kusuma, H.E. (2016). Pemahaman Masyarakat terhadap Faktor Struktural dan Non-struktural Rumah Tahan Gempa, Prosiding Seminar Nasional Temu Ilmiah IPLBI 2016, IPLBI dan ITN Malang.

Harmankaya, Z.Y., \& Soyluk, A. (2012). Architectural Design of Irregular Buildings in Turkey. International Journal of Civil \& Environmental Engineering IJCEE-IJENS, 12(1), 42-48.

IFRC \& RCS (2011). Public awareness and public education for disaster risk reduction: a guide. International Federation of Red Cross and Red Crescent Societies.Geneva.

Kaiser, H.F. (1960) The application of electronic computers to factor analysis. Educational and Psychological Measurement, 20(1), 141-151.

Kateri, M. (2014). Contingency Table Analysis: Methods and Implementation Using R, Springer, New York.

Kung, Y. W., \& Chen, S. H. (2012). Perception of earthquake risk in Taiwan: Effects of gender and past earthquake experience. Risk Analysis, 32(9), 1535-1546.

Kusumastuti, D., Pribadi, K.S., \& Rildov (2008). Reducing Earthquake Vulnerability of NonEngineered Buidings: Case Study of Retrofitting of School Building in Indonesia. The $14^{\text {th }}$ World Conference on Earthquake Engineering. Beijing, China.

Jolliffe, I.T. (2002). Principal Component Analysis, 2nd ed., Springer, New York.

Mora, K., Chang, J., Beatson, A., \& Morahan, C. (2015). Public perceptions of building seismic safety following the Canterbury earthquakes: A qualitative analysis using Twitter and focus groups. International Journal of Disaster Risk Reduction, 13, 1-9. Elsevier Ltd.

Neuman, L.W. (2014). Social Research Methods: Qualitative and Quantitative Approaches. Pearson Education Limited, USA.

Riduwan \& Sunarto, H. (2010). Pengantar Statistika untuk Penelitian: Pendidikan, Sosial, Komunikasi, Ekonomi, dan Bisnis, Penerbit Alfabeta, Bandung.

Singh, S.R., Eghdami, M.R., \& Singh, S. (2014). The Concept of Social Vulnerability: A Review from Disasters Perspectives. International Journal of Interdisciplinary and Multidisciplinary Studies (IJIMS), 1(6), 71-82. http://www.ijims.com. Diunduh 1 Maret 2017.

Sugiyono (2017) Metode Penelitian Kuantitatif Kualitatif dan R\&D, Penerbit Alfabeta, Bandung.

Ozmen, C., \& Unay, A.I. (2007). Commonly encountered seismic design faults due to the architectural design of residential buildings in Turkey. Building and Environment, 42, 1406-1416. Elsevier Ltd.

Vicente, R., Ferreira, T.M., Maio, R., \& Koch, H. (2014) Awareness, Perception and Communication of Earthquake Risk in Portugal: Public Survey, Procedia Economics and Finance, 18, 271-278. 